\title{
The emergence of social licence necessitates reforms in environmental regulation
}

\author{
$\underline{\text { Ingrid E. van Putten }}^{1,2}$, Christopher Cvitanovic ${ }^{1,2}$, Elizabeth Fulton ${ }^{1,2}$, Justine Lacey $^{3}$ and Rachel Kelly $^{2,4}$
}

\begin{abstract}
The term "social licence to operate" (SLO), popularized in corporate usage over the last 20 years, is frequently used to refer to the level of social approval that exists in relation to the development of natural resources for private or public purposes. However, the theoretical and practical utility of the concept remains contested and it is often used opportunistically to advance individual agendas. Moreover, it remains difficult to assess how an adequate level of SLO can be transparently assessed, or how dialogue can be appropriately achieved. In this paper we argue that the increasing use of the SLO concept is an indication that trust in, and the legitimacy of, formal regulatory processes for natural resource management has eroded and needs to be reimagined. In response, we outline five principles that provide pathways to increase the legitimacy of, and trust in, regulatory approval processes: (i) clear regulatory objectives; (ii) transparent regulatory approval processes; (iii) clear pathways for appeals and reviews of regulatory decisions (iv) early and inclusive collaborative consultation process; and (v) independence of decision-making authorities. By rethinking the basic principles of regulatory and licencing processes in natural resource management, our five principles aim to reduce the need for SLO. This could minimize erratic decision making and inequitable approval processes that are driven by a perceived need for SLO, often only for the corporate sector, which risks the voices of other stakeholders being unevenly represented. We draw upon natural resource management experiences from Tasmania, Australia as illustrative examples to stimulate a discussion on the usefulness of SLO and the need for improved approaches to natural resource management.
\end{abstract}

Key Words: environmental management; governance; legitimacy; resource conflict; trust

\section{INTRODUCTION}

Natural resources provide many benefits to society, but societal acceptance of natural resource use by the private sector may be affected if it imposes a negative effect on society. There are critical thresholds beyond which the level of societal benefits obtained from natural resources is diminished (Lubchenco et al. 1991) and the quality of the resource itself is affected. As a result, we have seen the rapid emergence of the term "social licence to operate" (SLO) in the private sector, used to describe the level of social approval that exists in relation to the development or use of common pool resources for private or public purposes (Moffat et al. 2016). Specifically, SLO refers to the initial approval and ongoing acceptance of resource extraction or industrial activity by local communities and other stakeholders affected by such activities (Parsons and Moffat 2014). The degree to which this acceptance is granted is rooted within the beliefs and worldviews of these local communities and stakeholders and underpinned by the extent to which an industry can establish meaningful and trusted partnerships with local communities.

Despite the recent and widespread adoption of SLO in relation to the management of common pool resources, the theoretical and practical utility of the concept remains contested (Parsons and Moffat 2014, Moffat et al. 2016). For example, given the numerous ways in which SLO has been applied across different sectors, settings, and geographies, it has proven difficult to define and in some cases, has been manipulated and used opportunistically to advance private agendas (Bice and Moffat 2014, Lester 2016). Even when a collective or consensual understanding of the term is established among diverse stakeholder groups, assessment of how these levels of social approval or acceptance might be transparently determined and agreed upon can be challenging (Prno 2013, Parsons and Moffat 2014), undermining the perceived legitimacy of the action, e.g., industrial development.

Despite the shortcomings of our collective understanding of SLO, increased media attention on industry activities (e.g., Leith et al. 2014), coupled with growing societal pressure and expectations on industry (Hanna et al. 2016), force the private sector to work actively to obtain and maintain SLO. Given the potential shortcomings of SLO, however, we contend that although operators and regulators both have a part to play in building public trust, public engagement and confidence in the activities that impact the sustainability of common pool natural resources should be primarily (and most easily) established through formal environmental regulatory and assessment processes. There is no obvious evidence that formal processes and requirement by the regulator would crowd out any voluntary action by the private sector to gain social acceptability (Hult 2018). However, public trust and legitimacy in environmental regulation has eroded over time and needs to be reimagined to better fulfil this purpose (Stern and Baird 2015).

We explore the proposition that growing pressure to obtain SLO has developed in response to the erosion of public trust in government structures and processes, and the legitimacy of environmental regulation. Drawing upon the existing literature on environmental governance we identify five principles that can be applied to reform regulatory processes, which we believe will increase public trust and legitimacy in environmental regulation. We anticipate that adopting these five principles should effectively

${ }^{1}$ Oceans and Atmosphere, CSIRO, Castray Esplanade, Hobart, Tasmania, Australia, ${ }^{2}$ Centre for Marine Socioecology, University of Tasmania, Hobart, Tasmania, Australia, ${ }^{3}$ Land and Water, CSIRO, Brisbane, Australia, ${ }^{4}$ Institute for Marine \& Antarctic Studies, Hobart, Tasmania, Australia 
reduce the need for SLO and allay undue reliance on unclear requirements associated with it. At the same time it should also strengthen the commitment to sustainability principles and process rigour that can ensure positive outcomes for society and the environment. In our exploration we develop inductive theory using the principles of good governance (Lockwood et al. 2010, McCall and Dunn 2012, Cullen-Knox et al. 2017) and use natural resource management experiences in Tasmania, Australia as illustrative examples to stimulate a discussion on the usefulness of SLO and the need for improved approaches to natural resource management.

\section{OVERVIEW OF SLO}

Modern communities have increased expectations about their role in decision making in resource development projects and how the benefits of resource development will be distributed and shared (Prno 2013). The resource sector has recognized this and attempted to respond in order to meet societal expectations around industry performance (mostly of an environmental and/ or social nature) leading to the wide adoption of the concept of SLO.

Originally, the concept of SLO emerged in response to environmental conflicts between resource extraction industries and communities (Thomson and Boutilier 2011) and over the last 20 years, the term has been popularized by the mining industry as a response to managing their social and reputational risk. The term is also progressively being applied and adopted across a range of other natural resource industries to describe the changing nature of the interactions among private companies and local communities (Hall et al. 2015, Moffat et al. 2016, Kendal and Ford 2018). Although social licence suggests a role in environmental regulation, there is actually no legal process for attaining it (Bursey and Whiting 2015). Rather, SLO is an informal contract between industry (or others) and communities that is awarded and maintained on the basis of transparent, ethical, and responsible use of natural resources, as perceived by community groups (Boutilier et al. 2012).

Since entering the mainstream discourse in the 1990s (Boutilier 2014), SLO has been broadly used to describe the initial approval and ongoing acceptance of industry activities by local communities and the stakeholders who can influence the viability of those activities (Parsons and Moffat 2014). Acceptance is underpinned by the extent to which an industry can establish meaningful partnerships with local communities that are built on mutual norms, trust, and communication (Moffat and Zhang 2014, Hall et al. 2015). Where there is a lack of societal support or outright opposition to natural resource development activities this is expressed as a lack of SLO. SLO does not have legal standing, but public opposition can strongly influence the success of industry activities, and industries now recognize the need to obtain SLO to avoid potentially costly conflict with community groups (Prno 2013).

Exploring the SLO literature, the three most widely referenced conceptual models of SLO are the following: (1) the pyramid model (Boutilier and Thomson 2011, unpublished manuscript, https://socialicense.com/publications/Modelling $\% 20$ and $\% 20$ Measuring $\%$ 20the $\% 20$ SLO.pdf), (2) the three strand model (Morrison 2014), and (3) the triangle model (Wüstenhagen et al. 2007). Each model stems from different origins and illustrates different aspects of the concept (see Appendix 1), but all are underpinned by the common concepts of trust and legitimacy (Colton et al. 2016). The pyramid model suggests there are four different stages in attaining SLO: withdrawal, acceptance, approval, psychological identification (Boutilier and Thomson 2011, unpublished manuscript). The three strand model relates SLO to legal, political, and economic licence and outlines the types of actors in each licence domain (Morrison 2014). The triangle model provides detail on the types of acceptance required for SLO, including socio-political, community, and market acceptance (Wüstenhagen et al. 2007).

In all three models the importance of legitimacy and trust are considered critical to achieving socially acceptable and sustainable natural resource development and management outcomes. Legitimacy can be defined as the perceived fairness and procedural justice associated with processes and their outcomes. This definition combines an empirical measure of legitimacy (acceptance of a rule or institution as authoritative) and a normative argument concerning whether the authority possesses legitimacy (providing reasons that justify it; Bernstein 2005). Trust means that an entity has confidence that the behavior of some other entity will match their expectations (Cook 2001). Trust in regulatory processes is centered on believing in the reliability, truth, or ability of the regulatory agency (Pirson and Malhotra 2011) and the people that construct it, and is a core issue that deeply influences the level of faith in a regulatory process.

The relationship between trust and legitimacy is not straightforward. For instance, there may be lack of legitimacy even when trust is present. Further, conflict frequently arises where legitimacy and/or trust have been eroded (Stern and Baird 2015). This erosion in trust and legitimacy can run in parallel to an increase in societal pressure for natural resource developments to obtain SLO. If legitimacy and trust are strengthened through more formal, transparent, clear, and predictable processes, this can enhance their development between all relevant stakeholders. Navigating trust has become increasingly complex, however, as human interactions expand over multiple spatial, demographic, and information scales, and this has raised the related question on the legitimacy of activities. Trust dynamics in regulatory relationships are under-researched, and surprisingly little empirical research on trust has been conducted in the context of regulator-regulated or citizen-regulator relationships (Lange and Gouldson 2010).

Conceptually, when exploring the context of SLO, trust and legitimacy exist or are constructed between (1) the project proponent, (2) local community and other outside stakeholders, i.e., NGOs, (3) the regulatory body, i.e., decision makers and experts who will or will not authorize industry projects and activities, and (4) other project beneficiaries, including the consumers (Fig. 1).

As with any human relationship, SLO is a loosely defined concept and difficulties around the use of the concept, and associated concepts such as social "communities" and social accountability, are well documented (Shepheard and Martin 2008, Moffat et al. 2016). SLO is perceived to be about justice, i.e., responsibility, impact, standing, and interest, and it is embedded within an "inescapably discursive" process (Lester 2016). Further, it is decidedly unclear how meaningful dialogue, which SLO is 
Fig. 1. Conceptual representation of the trust and legitimacy relationships of different groups of actors (indicated in the white boxes) in the context of a natural resource development project. The top section represents the current situation and the bottom section represents the situation to build toward in which the need for social licence is replaced. In both the top and bottom sections the light grey arrows represent the legitimacy and trust relationships that currently underpin social licence. In the bottom section of the figure, the dashed arrows indicate the trust and legitimacy relationships that should be strengthened to reduce the need for social licence and the solid arrow represents the trust and legitimacy relationships that need to be built through a better regulatory process.

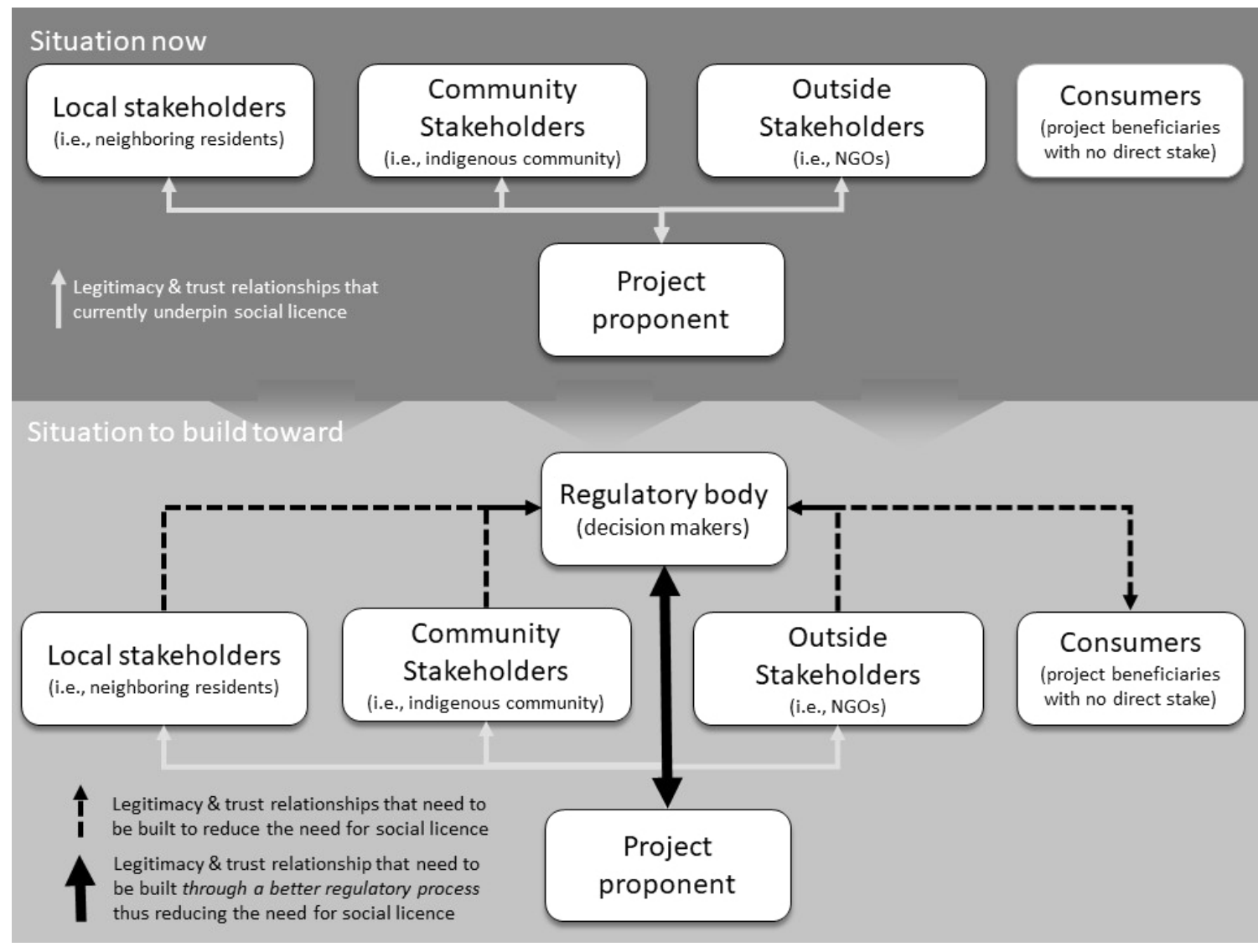

purportedly founded upon, is conducted and achieved (MercerMapstone et al. 2017). There is large consensus that the meaning of SLO is unclear, amorphous, and at times, confusing, it is "... not easy to find, difficult to measure, and capricious and dynamic in nature" (Douglas 2014:1). This has led some authors to suggest that regulators, policy makers, and politicians should refrain from using the term without a clear understanding of the implications (Colton et al. 2016). Arguably, defining SLO can be a futile enterprise: "We can't neatly define social license, but we know it when we see it" (U.S. Supreme Court Justice Stewart 1964, as cited in Douglas 2014:1)

We leave the discussion of the usefulness of the general concept of SLO to others. Rather, we highlight that current societal pressure on industry to secure a vaguely defined SLO, which demonstrates perceived legitimacy and acceptability of their activities, i.e., mining, fishing operations, windfarm developments, etc., might better be achieved through reformed, effective, and explicit regulatory pathways and processes. We draw on the principles of good governance (Lockwood et al. 2010, McCall and Dunn 2012, Cullen-Knox et al. 2017) to outline a way forward that will reduce the need for SLO.

\section{WAYS FORWARD WITHOUT SLO}

As we have shown, SLO is heavily influenced by trust and legitimacy, and vulnerable to complexities introduced by scale issues and information and power asymmetries. Moreover, SLO is contingent on personal and societal values and norms (Dare et al. 2014). Values are notions of what is right and important, and norms refer to behavioral expectations and how people should and should not behave (Stern 2000). Examples from the literature show that as the scale of interactions grow, tensions between stakeholders increase and engender changes in institutions and regulatory frameworks (Smidt 2003, Venticinque 2013, Christensen and Kyle 2014). Increased complexities exposed through expanding scales and growing societal asymmetries necessitate that fundamental regulatory processes be reimagined. We address this need in our description of five principles to improve the regulatory process below (Fig. 2). 
Table 1. Good governance principles as listed in selected peer reviewed papers and reports (principles listed in no particular order and original wording has been maintained as far as practical).

\begin{tabular}{|c|c|c|c|c|c|c|}
\hline $\begin{array}{l}\text { Governance } \\
\text { principles for } \\
\text { multilevel natural } \\
\text { resource } \\
\text { management } \\
\end{array}$ & $\begin{array}{l}\text { Principles of } \\
\text { relationships and } \\
\text { processes between } \\
\text { governing and } \\
\text { governed }\end{array}$ & $\begin{array}{l}\text { Principles of } \\
\text { governance } \\
\text { (forestry) }\end{array}$ & $\begin{array}{l}\text { Good governance } \\
\text { practice }\end{array}$ & $\begin{array}{l}\text { Principles that } \\
\text { support good } \\
\text { governance }\end{array}$ & $\begin{array}{l}\text { Principles of } \\
\text { Australian decision } \\
\text { making }\end{array}$ & $\begin{array}{l}\text { Context of donor } \\
\text { organizations (i.e., } \\
\text { NGOs) }\end{array}$ \\
\hline $\begin{array}{l}\text { (Lockwood et al. } \\
\text { 2010) }\end{array}$ & $\begin{array}{l}\text { (McCall and Dunn } \\
\text { 2012) }\end{array}$ & (FAO 2011) & $\begin{array}{l}\text { (Smith and } \\
\text { Jentoft 2017) }\end{array}$ & (OECD 2013) & $\begin{array}{l}\text { (Cullen-Knox et al. } \\
\text { 2017) }\end{array}$ & (van Doeveren 2011) \\
\hline Legitimacy & Legitimacy & Transparency & Transparent & Engagement & $\begin{array}{l}\text { Incorporate } \\
\text { differing views }\end{array}$ & $\begin{array}{l}\text { Openness and } \\
\text { transparency }\end{array}$ \\
\hline Transparency & Respect & $\begin{array}{l}\text { Fairness and } \\
\text { equity }\end{array}$ & Inclusive & $\begin{array}{l}\text { Accountability and } \\
\text { transparency }\end{array}$ & Adaptive & Participation \\
\hline Fairness & Equity & Participation & Open & $\begin{array}{l}\text { Performance } \\
\text { evaluation }\end{array}$ & Flexible & Accountability \\
\hline Inclusiveness & Accountability & Accountability & & $\begin{array}{l}\text { Independent } \\
\text { regulators }\end{array}$ & $\begin{array}{l}\text { Reliable and useful } \\
\text { knowledge }\end{array}$ & $\begin{array}{l}\text { Efficiency and } \\
\text { effectiveness }\end{array}$ \\
\hline Accountability & Competence & Effectiveness & & $\begin{array}{l}\text { Maintenance of } \\
\text { trust }\end{array}$ & & Rule of law \\
\hline Adaptability & & Efficiency & & $\begin{array}{l}\text { Prevention of } \\
\text { undue influence }\end{array}$ & & \\
\hline Capability & & & & Funding & & \\
\hline Integration & & & & Role clarity & & \\
\hline
\end{tabular}

Fig. 2. Conceptual model of the five solutions (and interactions between them) offered through reimagining the regulatory processes and how they will affect social licence (in the black box) by way of positive drivers of change (trust and legitimacy). Also shown are the external factors that influence trust and legitimacy.

\section{Change solutions in the regulatory process}

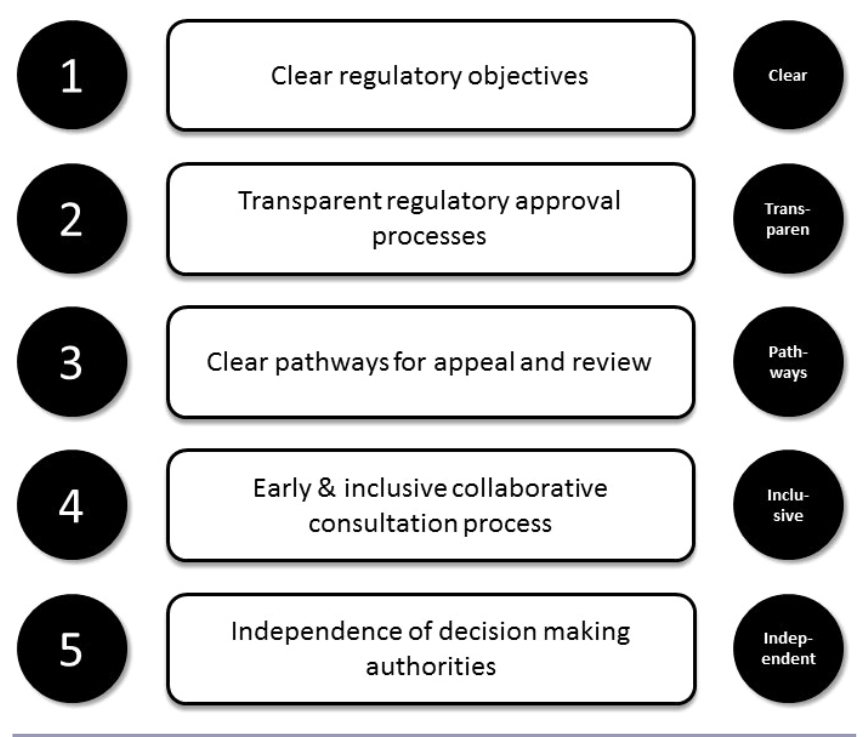

Five principles for improving regulatory processes

The five principles we present here center on fundamental premises that are demonstrated to be key to good governance in environmental regulatory processes. Research articles that focus on good governance do not all identify five premises or principles. Rather, we have drawn from the extant literature to identify the five overarching principles presented in Table 1.

The principles shown in Table 1 are not an exhaustive list and there are many more documents that outline good governance principles. For example in Australia, a report by the Department of Agriculture and Forestry outlines 10 leading governance practices for development proposals and development assessments (Development Assessment Forum 2005). The literature shown in Table 1 was selected mainly because of its relevance to natural resource management.

\section{Tasmania as a case study}

We outline the five principles that we believe could be applied to reform regulatory processes to reduce the need for SLO, and illustrate their importance using experiences in Tasmania, Australia, as a case study. In doing so we acknowledge that the regulatory requirements and mechanisms for natural resource developments are not uniform across industry or jurisdiction (even within Australia).

There are four reasons that Tasmania was chosen as a case study: it is a relatively small island, i.e., geographically bounded, and thus, at a scale arguably more manageable for study; it has a wellknown environmental history with one of the most significant environmental campaigns in Australian history occurring in reaction to the Gordon-below-Franklin dam (Bandler 1987); it is an Australian State, i.e., jurisdictionally bounded; and it has an integrated and well-functioning planning system. Tasmania is also known for its pristine environments, and as the birthplace of a national environmental movement (Hay 1994), and there have been major reforms to environmental policy in Tasmania over the past decades (Stratford 2008).

The island of Tasmania is also an Australian State, which bounds the legislation relevant to our premise. Constitutional authority 
for planning in Australia rests with the states (Ruming and Gurran 2014) and is not coordinated by the national government. Tasmania has an independent review tribunal and there is institutional separation of the environmental assessment and enforcement functions from the environmental policy functions (Development Assessment Forum 2005, Productivity Commission 2013). Tasmania also has a leading practice, in that it specifies a consistent schedule of objects across its legislation and a set of objectives is included in a schedule to each of the acts within the Resource Management and Planning System, to ensure that all decisions about the use of land and natural resources within the state are made in pursuit of common objectives (Land Use and Planning Approvals Act 1993, schedule 1).

In broad terms, assessment arrangements in Tasmania can be characterized as relatively integrated. Of all the Australian states, independent major project assessment arrangements are perhaps most developed in Tasmania, where the Tasmanian Planning Commission (an independent statutory body under the Tasmanian Planning Commission Act 1997) is responsible for conducting an integrated assessment of projects of state significance. The commission then makes recommendations to the minister. Reforms that have taken place with respect to the planning system in the unique economic and environmental context of Tasmania have been studied by, for instance, Castles and Stradford (2014).

\section{Clear regulatory objectives}

Place-based regulatory objectives for use of natural resources (that are sensitive to higher level ecological limits) set the boundary conditions for the natural resource use development. This may also be considered as setting the limits of acceptable change. Resource use objectives should be clearly articulated and defined before a development project is even raised and they should not be determined internally within government processes. Pathways for appeal and review can assure stakeholders that avenues are available to ensure that these boundary conditions are actually met.

Objectives should be agreed upon by fair processes, which fundamentally require collaborative consultation (Dichmont et al. 2016, Dutra et al. 2016, Van Putten et al. 2016). For instance, high-level, spatially explicit objectives for marine areas in Australia are particularly important to manage increasingly crowded inshore spaces. The issue of unclear objectives for an inshore area developed into an SLO issue in Ralphs Bay, Tasmania in 2004 (MacDonald and Feehely 2010). A canal development was proposed for Ralphs Bay (Stratford 2009) and it soon became apparent that the public, government, and developers had vastly different and conflicting objectives for the area, including conservation, residential areas, and tourism. Objectives had not been clearly (or collaboratively) defined prior to the development proposal submission. The proponents were eventually denied the right to proceed with the canal development after consideration by an independent statutory body of the planning arm of the Tasmanian Government (Stratford 2009).

The importance of using collaborative consultation to develop and prioritize clear objectives is expected to contribute to increased transparency and trust. For example, in a fisheries context, when use-rights are assigned, i.e., allocation of individual tradeable quota under a total allowable catch system, the objectives associated with the introduction of new management, e.g., a profitable industry and sustainable environment, must be carefully defined. Principally, because future use is likely to have negative impact on those for whom access will be denied (Buxton and Cochrane 2016, Emery et al. 2016). In the mid-1980s in Tasmania, a consultative process, which as not strictly a collaborative consultation process as we defined it, was used in the rock lobster and abalone fisheries to introduce management change. The interactions that this process facilitated likely contributed to greater clarity around the objectives for changing the management approach, even if not all the proponents agreed on the approach used to meet these objectives (Bradshaw 2004). Collaborative processes in the development of a new management system provided an opportunity to assess the diversity of views, while also working toward a sustainable natural resource management solution.

\section{Transparent regulatory approval processes}

The importance of transparency in the regulatory approval process would seem self-evident, particularly following the impacts of the global economic and financial crisis that highlighted major flaws in governance and regulations systems that undermined public trust in both government and private sector institutions. According to the OECD (2012), the principles of transparency and participation in regulatory processes support outcomes that serve the public interest and that are legitimately informed by the interests and needs of those affected by such regulation. When approvals for developments are submitted to governing agencies, the steps and requirements of potential approvals need to be outlined clearly so that stakeholders with an interest in the development can independently assess whether appropriate and just procedures are being followed. Looking again at our Tasmanian example, an approval process associated with a pulp mill proposal in the north of the island in 2013 evolved into a SLO debacle (Lester 2016). Instead of revealing the project approval process to the public and other proponents, the project was removed from the independent assessment process of the Resource Planning and Development Commission (RPDC), and assessment and project-specific, i.e., less transparent, legislation was politically approved without any public input (http://www. parliament.tas.gov.au/bills/Bills2014/1 of 2014.htm). Subsequent assessment by the government provoked suspicion around the process and it was perceived to be opaque to scrutiny, as well as politically biased (Lester 2016). Dubious alliances between the government and proponents further deepened this SLO controversy. The process eventually led to Gunns Limited deciding not to proceed with a pulp mill development in the area (Gale 2008, Lester 2016).

\section{Clear pathways for appeal and review}

Clearly articulated resource-use objectives are important, but clarity in the pathways available for appeal and review before and during development projects are also key to trust and legitimacy, especially where the regulator is seen to be rigorously enforcing the law on behalf of the public. A cooperative (or compliancebased) regulatory style is more likely to be based on higher levels of three-way trust and collaboration, i.e., between regulators, project proponents, and the community (Lange and Gouldson 2010) than an adversarial or sanctions-based regulatory style (Stern 2008). 
"To ensure predictability of process there should be a clear procedure for all steps of the grievance handling and dispute resolution process" (Kemp and Gotzmann 2009:18). Clearly defined pathways for appeal that are not perceived as (too) restrictive, but nevertheless based on objective, i.e., collaboratively defined, criteria, will ensure that some of the most difficult to control aspects of SLO are addressed (Kemp and Gotzmann 2009), e.g., provide a chance for the voices of all stakeholders to be heard. These principles align with 2008 United Nations Directive Clause 82, page 22(UN Human Rights Council 2008).

In Tasmania, there are essentially three pathways for review in assessment and approval processes (Productivity Commission 2013): (1) merit review (the Appeal Tribunal on a local council planning decision); (2) judicial review (to the Supreme Court on a matter of process not merit); and (3) Parliamentary review (in the case of Projects of State Significance, there is an opportunity to disallow an approval that is different to that recommended by the independent commission). These linked but independent processes are clearly defined and cater for different types of review needs and access.

Where previously clearly outlined approval processes are opportunistically changed, this may affect trust and legitimacy. For instance, the approval process for the Gunns Limited pulp mill development (Gale 2008, Lester 2016) discussed above was removed from an independent assessment to project-specific legislation. This legislation did not provide a clear avenue for review and appeals affecting the company's SLO and the perception of hidden processes and lack of transparency likely further degraded public trust and SLO (Lester 2016).

Early and inclusive collaborative consultation process

Both clarity and transparency are mediated by implementing an inclusive collaborative consultation process (Idol et al. 1995) ${ }^{[1]}$ Simple participation might not be sufficient to create trust, whereas collaborative consultation can help to create and sometimes reinforce trust (Kemp and Gotzmann 2009, Miller and Nadeau 2017). There are many ways to implement public participation and deliberation to rebuild trust and positively influence the ecological standard of decisions; for example, by using face-to-face communication (Newig and Fritsch 2009) and the involvement of professionals (Tsang et al. 2009). Stakeholder involvement in the collaborative consultation process should commence early, i.e., in the scoping phase of project proposals and impact assessments. For instance, impact assessments are part of the development application process in many jurisdictions. These impact assessments may be seen by companies as doublebind because they expose risks, but the exposure of risks in itself could give the impression of transparency and potentially build trust (see Renn and Schweizer 2009 for concept of inclusive risk governance). Even in situations where trust has been lost, or meagre trust exists, an open dialogue can build a shared understanding of the various interests and facilitate compromise (Díez et al. 2015) building longer-term trust (Gouldson et al. 2007).

The SLO issue that arose in reaction to the Abel Tasman super trawler in Tasmania and adjacent waters (Haward et al. 2013, Tracey et al. 2013, Wainwright 2015) in 2012 may have been avoided had a collaborative consultation process been implemented earlier. The super trawler was banned from operating by the federal authority even though all biological and operating requirements were met in the formal approval processes (Haward et al. 2013). The current decision making and approval process in Tasmania (and Australian federal fisheries) includes stakeholder participation in impact assessment, but stakeholders who are not directly involved may be ignorant of the current consultation process. Consultation of the broader group of stakeholders, earlier in the approval process might be required to gain the trust of resource users as well as the regulators, who in this case, revoked their approval of the super trawler, increasing suspicion and reducing public trust in the approval process (Buxton et al. 2013).

Given the range and diversity of values held by the public, the question remains as to who should participate in the collaborative consultation process (Alberts 2007) and be engaged in setting resource management objectives to achieve a clearer theoretical, as well as more transparent, regulatory and approval process (Productivity Commission 2013). Fundamentally, the means by which different groups of people are selected to be included in the official process must be a fair and accountable (Parsons et al. 2014). Collaborative consultation should be accessible and adequate and provide people from different backgrounds "an opportunity to participate in a meaningful way" (Colton et al. 2016:105).

A wind farm proposal in King Island in 2012, off the north coast of Tasmania, did not proceed allegedly because of low-projected financial returns but purportedly, SLO issues that arose also played a role (Corscadden et al. 2012, Anderson 2013, Colvin et al. 2016). In this case, the deliberation processes were implemented early when the proposal was first muted, but because of the apparent haphazard nature of consultation and information dispersal (and the proponent itself setting an arbitrary measure of SLO at $60 \%$ of public approval) the proponents were met with an SLO issue from components of the community that contributed to community conflict. Had the process been more accessible and had stronger formal processes for deliberation been available, it is likely that the outcomes could have been different in terms of earning SLO for this wind farm development.

\section{Independence in decision making}

The regulatory approval process is complex and working to accommodate social acceptance is a challenging process. "Perceptions of independence and hence an absence of inappropriately shared interests are key to whether citizens trust regulators or scientists" (Lange and Gouldson 2010:5237). Regulatory proceedings typically involve lengthy submissions by various stakeholders and interveners, and often by various governmental entities. Where evidence is given and tested under oath, this may contribute to the credibility of the process and may bolster public acceptability. However, most independent assessments are not courts that require the provision of evidence under oath. In fact, it can be argued that though courts or tribunals provide independence, the more formal and legalistic they are, the less accessible they become to the public. They are thus likely to favor the wealthy, well-educated, and well-resourced who have the capacity to engage in these sessions, and employ lawyers, etc.

Although acknowledging that adversarial procedures are costly in terms of time and resources, we still argue that they can serve 
an important purpose, within which interrogatory processes and cross-examination are important tools. However, such crossexamination, and indeed the entire regulatory proceeding, must also reflect the anticipated magnitude of impacts of the ultimate decision (Colton et al. 2016). The Ralphs Bay project (MacDonald and Feehely 2010) was denied and the final decision accepted by proponents because the arbitrators were seen as being at arm's length from the government. The independent and courtlike proceedings purportedly assured local people and provided a feeling of transparency. The proposed canal development in Ralphs Bay was eventually overturned by the Tasmanian Planning Commission (MacDonald and Feehely 2010, Tasmanian Planning Commission 2010). The independent decision process seems to have been successful in creating acceptance and purportedly created trust in the process, which can be of future benefit to similar situations.

\section{CONCLUSION}

Natural resources are undeniably and increasingly complicated to share, contain, and manage, and necessitate various complex management strategies and procedures. Reliance on SLO presents a danger of introducing an undefined concept, prone to different interpretations, into a natural resource development approval process that requires clarity and transparency. Rather than requiring a shift in the way governments function, the focus of SLO to date has been narrowly on industry with the exclusion of government, with no clear guidelines for how industry might be adapting in line with these societal responses.

We contend that the need for a public statement of SLO as a prerequisite to development approval can be reduced if the key elements of SLO, i.e., trust and legitimacy, can be systematically enhanced through regulatory and assessment processes. A more formalized path toward creating trust and legitimacy can ensure that the process of gaining an SLO need not be reinvented every time a development application is put forward. If there is legitimacy and trust in institutions (thus, indirectly in the regulatory and licencing process), we argue that there is no reason to believe formal processes and requirements would crowd out any additional voluntary action by industry (Grepperud 2007); private responsibility for good governance should be maintained. SLO can be explored when these formal processes and requirements no longer protect or represent community interests and expectations.

We explicate five principles of good governance that have been distilled from the extant literature on environmental governance, and highlight experiential evidence from Tasmanian to justify our argument that these five principles present clear pathways to reform regulatory processes. Reform has great potential to increase public trust and legitimacy in environmental regulation. To recapitulate, our five key principles comprise the following: (i) clear regulatory objectives; (ii) transparent regulatory approval processes; (iii) clear pathways for appeals and reviews of regulatory decisions; (iv) early and inclusive collaborative consultation process (Ostrom 2009, Productivity Commission 2013); and (v) independence of decision-making authorities. We argue that adopting these principles will contribute to increasing trust and legitimacy by influencing positive drivers of change, increasing social capital, and reducing reliance on SLO that requires reinterpretation with every new development proposal.
Implementing these key principles must go hand in hand with ongoing research that is developing locally appropriate natural resource governance structures, to ensure that the best environmental and socially equitable outcomes can be achieved.

${ }^{[1]}$ Collaborative consultation is defined as an "interactive process that enables people with diverse expertise to generate creative solutions to mutually defined problems" (Idol et al. 1995:329).

Responses to this article can be read online at: http://www.ecologyandsociety.org/issues/responses. php/10397

\section{Acknowledgments:}

We would like to thank Peat Leith and Mary Mackay who provided early comments on the manuscript. We also thank the two anonymous reviewers for their helpful comments.

\section{LITERATURE CITED}

Alberts, D. J. 2007. Stakeholders or subject matter experts, who should be consulted? Energy Policy 35(4):2336-2346. http://dx. doi.org/10.1016/j.enpol.2006.08.006

Anderson, C. 2013. The networked minority: how a small group prevailed in a local windfarm conflict. Energy Policy 58:97-108. http://dx.doi.org/10.1016/j.enpol.2013.02.048

Bandler, H. 1987. Gordon below Franklin Dam, Tasmania, Australia: environmental factors in a decision of national significance. Environmentalist 7(1):43-54. http://dx.doi.org/10.1007/ $\underline{\mathrm{BF} 02277205}$

Bernstein, S. 2005. Legitimacy in global environmental governance. Journal of International Law \& International Relations 1(1-2):139-166.

Bice, S., and K. Moffat. 2014. Social licence to operate and impact assessment. Impact Assessment and Project Appraisal 32 (4):257-262. http://dx.doi.org/10.1080/14615517.2014.950122

Boutilier, R. G. 2014. Frequently asked questions about the social licence to operate. Impact Assessment and Project Appraisal 32 (4):263-272. http://dx.doi.org/10.1080/14615517.2014.941141

Boutilier, R. G., L. Black, and I. Thomson. 2012. From metaphor to management tool: how the social license to operate can stabilise the socio-political environment for business. Pages 227-237 in International Mine Management 2012 Proceedings. Australian Institute of Mining and Metallurgy, Melbourne, Australia.

Bradshaw, M. 2004. A combination of state and market through ITQs in the Tasmanian commercial rock lobster fishery: the tail wagging the dog? Fisheries Research 67(2):99-109. http://dx.doi. org/10.1016/j.fishres.2003.11.007

Bursey, D. W., and V. Whiting. 2015. Rethinking social licence to operate - a concept of search of definition and boundaries. Environment and Energy Bulletin Business Council of British Columbia 7(2):1-10. 
Buxton, C., and P. Cochrane. 2016. The story behind Australia's marine reserves, and how we should change them. The Conversation, 2 October.

Buxton, C., C. Gardner, J. M. Lyle, and R. Hilborn. 2013. Super trawler gone, but is fisheries policy in trouble? The Conversation, 12 March.

Castles, A., and E. Stratford. 2014. Planning reform in Australia's island-state. Australian Planner 51(2):170-179. http://dx.doi. org/10.1080/07293682.2014.890942

Christensen, P., and D. G. Kyle. 2014. A companion to sport and spectacle in Greek and Roman Antiquity. Wiley \& Sons, Chichester, UK.

Colton, J., K. Corscadden, S. Fast, M. Gattinger, J. Gehman, M. Hall Findlay, D. Morgan, J. Sayers, J. Winter, and A. Yatchew. 2016. Energy projects, social licence, public acceptance and regulatory systems in Canada: a white paper. University of Calgary, The School of Public Policy, Calgary, Alberta, Canada. http://dx.doi.org/10.2139/ssrn.2788022

Colvin, R. M., G. B. Witt, and J. Lacey. 2016. How wind became a four-letter word: lessons for community engagement from a wind energy conflict in King Island, Australia. Energy Policy 98:483-494. http://dx.doi.org/10.1016/j.enpol.2016.09.022

Cook, K. S. 2001. Trust in society. Russell Sage Foundation, New York, New York, USA.

Corscadden, K., A. Wile, and E. Yiridoe. 2012. Social license and consultation criteria for community wind projects. Renewable Energy 44:392-397. http://dx.doi.org/10.1016/j.renene.2012.02.009

Cullen-Knox, C., M. Haward, J. Jabour, E. Ogier, and S. R. Tracey. 2017. The social licence to operate and its role in marine governance: insights from Australia. Marine Policy 79 (Supplement C):70-77. http://dx.doi.org/10.1016/j.marpol.2017.02.013

Dare, M., J. Schirmer, and F. Vanclay. 2014. Community engagement and social licence to operate. Impact Assessment and Project Appraisal 32(3):188-197. http://dx.doi.org/10.1080/1461$\underline{5517.2014 .927108}$

Development Assessment Forum. 2005. A leading practice model for development assessment in Australia. Planning Institute Australia, Kingston, Australian Capital Territory, Australia.

Dichmont, C. M., L. X. C. Dutra, R. Owens, E. Jebreen, C. Thompson, R. A. Deng, E. I. van Putten, R. Pascual, J. M. Dambacher, M. S. J. Warne, R. H. Quinn, O. Thébaud, J. Bennett, M. Read, D. Wachenfeld, J. Davies, A. Garland, M. Dunning, C. Collier, M. Waycott, and J. Playford. 2016. A generic method of engagement to elicit regional coastal management options. Ocean \& Coastal Management 124:22-32. http://dx.doi.org/10.1016/j. ocecoaman.2016.02.003

Díez, M.-A., I. Etxano, and E. Garmendia. 2015. Evaluating participatory processes in conservation policy and governance: lessons from a Natura 2000 pilot case study. Environmental Policy and Governance 25(2):125-138. http://dx.doi.org/10.1002/eet.1667

Douglas, G. 2014. "I know it when I see it": where to look for social license. In International Pipeline Conference IPC2014 September 29-October 3, Calgary, Alberta, Canada. http://dx. doi.org/10.1115/IPC2014-33599
Dutra, L. X. C., C. M. Dichmont, I. E. van Putten, O. Thébaud, R. A. Deng, R. Pascual, R. Owens, E. Jebreen, C. Thompson, M. S. J. Warne, R. Quinn, J. Bennett, M. Read, D. Wachenfeld, C. Collier, M. Waycott, J. Davies, A. Garland, M. Dunning, and J. Playford. 2016. How important is the coast? A survey of coastal objectives in an Australian regional city. Marine Policy 71:229-241. http://dx.doi.org/10.1016/j.marpol.2016.05.020

Emery, T. J., C. Gardner, K. Hartmann, and I. Cartwright. 2016. The role of government and industry in resolving assignment problems in fisheries with individual transferable quotas. Marine Policy 73:46-52. http://dx.doi.org/10.1016/j.marpol.2016.07.028

Food and Agriculture Organization (FAO). 2011. Framework for assessing and monitoring forest governance. FAO, Rome, Italy.

Gale, F. 2008. Tasmania's Tamar Valley Pulp Mill: a comparison of planning processes using a good environmental governance framework. Australian Journal of Public Administration 67 (3):261-282. http://dx.doi.org/10.1111/j.1467-8500.2008.00586.x

Gouldson, A., R. Lidskog, and E. Wester-Herber. 2007. The battle for hearts and minds? Evolutions in corporate approaches to environmental risk communication. Environment and Planning $C$ : Politics and Space 25(1):56-72. http://dx.doi.org/10.1068/c0617j

Grepperud, S. 2007. Environmental voluntary behaviour and crowding-out effects: regulation or laissez-faire? European Journal of Law and Economics 23(2):135-149. http://dx.doi.org/10.1007/ $\underline{\text { s10657-007-9008-8 }}$

Hall, N., J. Lacey, S. Carr-Cornish, and A.-M. Dowd. 2015. Social licence to operate: understanding how a concept has been translated into practice in energy industries. Journal of Cleaner Production 86:301-310. http://dx.doi.org/10.1016/j.jclepro.2014.08.020

Hanna, P., F. Vanclay, E. J. Langdon, and J. Arts. 2016. Conceptualizing social protest and the significance of protest actions to large projects. Extractive Industries and Society 3 (1):217-239. http://dx.doi.org/10.1016/j.exis.2015.10.006

Haward, M., J. Jabour, and J. McDonald. 2013. Small fish in a big pond: lessons from the Abel Tasman controversy. Australian Journal of Maritime \& Ocean Affairs 5(1):22-27. http://dx.doi. org/10.1080/18366503.2013.10815727

Hay, P. 1994. The politics of Tasmania's world heritage area: contesting the democratic subject. Environmental Politics 3 (1):1-21. http://dx.doi.org/10.1080/09644019408414122

Hult, D. 2018. Creating trust by means of legislation - a conceptual analysis and critical discussion. Theory and Practice of Legislation 6(1):1-23. http://dx.doi.org/10.1080/20508840.2018.1434934

Idol, L., P. Paolucci-Whitcomb, and A. Nevin. 1995. The collaborative consultation model. Journal of Educational and Psychological Consultation 6(4):329-346. http://dx.doi.org/10.1207/ $\underline{\mathrm{s} 1532768 \mathrm{xjepc} 06043}$

Kemp, D., and N. Gotzmann. 2009. Community complaints and grievance mechanisms and the Australian minerals industry. Centre for Social Responsibility in Mining, The University of Queensland, Brisbane, Australia.

Kendal, D., and R. M. Ford. 2018. The role of social license in conservation. Conservation Biology 32(2):493-495. http://dx.doi. org/10.1111/cobi.12994 
Lange, B., and A. Gouldson. 2010. Trust-based environmental regulation. Science of The Total Environment 408(22):5235-5243. http://dx.doi.org/10.1016/j.scitotenv.2010.07.052

Leith, P., E. Ogier, and M. Haward. 2014. Science and social license: defining environmental sustainability of Atlantic salmon aquaculture in south-eastern Tasmania, Australia. Social Epistemology 28(3-4):277-296. http://dx.doi.org/10.1080/026917$\underline{28.2014 .922641}$

Lester, L. 2016. Media and social licence: on being publicly useful in the Tasmanian forests conflict. Forestry: An International Journal of Forest Research 89(5):542-551. http://dx.doi. org/10.1093/forestry/cpw015

Lockwood, M., J. Davidson, A. Curtis, E. Stratford, and R. Griffith. 2010. Governance principles for natural resource management. Society \& Natural Resources 23(10):986-1001. http://dx.doi.org/10.1080/08941920802178214

Lubchenco, J., A. M. Olson, L. B. Brubaker, S. R. Carpenter, M. M. Holland, S. P. Hubbell, S. A. Levin, J. A. MacMahon, P. A. Matson, J. M. Melillo, H. A. Mooney, C. H. Peterson, H. R. Pulliam, L. A. Real, P. J. Regal, and P. G. Risser. 1991. The sustainable biosphere initiative: an ecological research agenda: a report from the Ecological Society of America. Ecology 72 (2):371-412. http://dx.doi.org/10.2307/2937183

MacDonald, J., and J. Feehely. 2010. Ralphs Bay saved - a Tasmanian story. National Environmental Law Review 01:38-47.

McCall, M. K., and C. E. Dunn. 2012. Geo-information tools for participatory spatial planning: fulfilling the criteria for 'good' governance? Geoforum 43(1):81-94. http://dx.doi.org/10.1016/j. geoforum.2011.07.007

Mercer-Mapstone, L., W. Rifkin, K. Moffat, and W. Louis. 2017. Conceptualising the role of dialogue in social licence to operate. Resources Policy 54(Supplement C):137-146. http://dx.doi. org/10.1016/j.resourpol.2017.09.007

Miller, L. F., and S. Nadeau. 2017. Participatory processes for public lands: do provinces practice what they preach? Ecology and Society 22(2):19. http://dx.doi.org/10.5751/ES-09142-220219

Moffat, K., J. Lacey, A. Zhang, and S. Leipold. 2016. The social licence to operate: a critical review. Forestry: An International Journal of Forest Research 89(5):477-488. http://dx.doi. org/10.1093/forestry/cpv044

Moffat, K., and A. Zhang. 2014. The paths to social licence to operate: an integrative model explaining community acceptance of mining. Resources Policy 39:61-70. http://dx.doi.org/10.1016/ j.resourpol.2013.11.003

Morrison, J. 2014. The social licence: how to keep your organization legitimate. Palgrave Macmillan, New York, New York, USA.

Newig, J., and O. Fritsch. 2009. Environmental governance: participatory, multi-level - and effective? Environmental Policy and Governance 19(3):197-214. http://dx.doi.org/10.1002/eet.509

Organisation for Economic Co-operation and Development (OECD). 2012. Recommendation of the Council on Regulatory Policy and Governance. OECD, Paris, France.
Organisation for Economic Co-operation and Development (OECD). 2013. Principles for the governance of regulators: public consultation draft. OECD Regulatory Policy Committee, Paris, France.

Ostrom, E. 2009. A general framework for analyzing sustainability of social-ecological systems. Science 325 (5939):419-422. http://dx.doi.org/10.1126/science.1172133

Parsons, R., J. Lacey, and K. Moffat. 2014. Maintaining legitimacy of a contested practice: how the minerals industry understands its 'social licence to operate.' Resources Policy 41:83-90. http://dx.doi.org/10.1016/j.resourpol.2014.04.002

Parsons, R., and K. Moffat. 2014. Constructing the meaning of social licence. Social Epistemology 28(3-4):340-363. http://dx.doi. org/10.1080/02691728.2014.922645

Pirson, M., and D. Malhotra. 2011. Foundations of organizational trust: what matters to different stakeholders? Organization Science 22(4):817-1120. http://dx.doi.org/10.1287/ orsc. 1100.0581

Prno, J. 2013. An analysis of factors leading to the establishment of a social licence to operate in the mining industry. Resources Policy 38(4):577-590. http://dx.doi.org/10.1016/j.resourpol.2013.09.010

Productivity Commission. 2013. Major project development assessment processes. Productivity Commission, Canberra, Australia.

Renn, O., and P.-J. Schweizer. 2009. Inclusive risk governance: concepts and application to environmental policy making. Environmental Policy and Governance 19(3):174-185. http://dx. doi.org/10.1002/eet.507

Ruming, K., and N. Gurran. 2014. Australian planning system reform. Australian Planner 51(2):102-107. http://dx.doi. org/10.1080/07293682.2014.896065

Shepheard, M. L., and P. V. Martin. 2008. Social licence to irrigate: the boundary problem. Social Alternatives 27(3):32.

Smidt, C. E. 2003. Religion as social capital: producing the common good. Baylor University Press, Waco, Texas, USA.

Smith, G., and S. Jentoft. 2017. Marine spatial planning in Scotland. Levelling the playing field? Marine Policy 84 (Supplement C):33-41. https://doi.org/10.1016/j.marpol.2017.06.024

Stern, M. J. 2008. Coercion, voluntary compliance and protest: the role of trust and legitimacy in combating local opposition to protected areas. Environmental Conservation 35(3):200-210. http://dx.doi.org/10.1017/S037689290800502X

Stern, M. J., and T. D. Baird. 2015. Trust ecology and the resilience of natural resource management institutions. Ecology and Society 20(2):14. http://dx.doi.org/10.5751/ES-07248-200214

Stern, P. C. 2000. New environmental theories: toward a coherent theory of environmentally significant behavior. Journal of Social Issues 56(3):407-424. http://dx.doi.org/10.1111/0022-4537.00175

Stratford, E. 2008. Islandness and struggles over development: a Tasmanian case study. Political Geography 27(2):160-175. http:// dx.doi.org/10.1016/j.polgeo.2007.07.007 
Stratford, E. 2009. Belonging as a resource: the case of Ralphs Bay, Tasmania, and the local politics of place. Environment and Planning A: Economy and Space 41(4):796-810. http://dx.doi. org/10.1068/a40198

Tasmanian Planning Commission. 2010. Integrated assessment report - Lauderdale Quay development proposal. Tasmanian Planning Commission, Hobart, Tasmania, Australia.

Thomson, I., and R. G. Boutilier. 2011. The social licence to operate. Pages 673-690 in P. Darling, editor. SME mining engineering handbook. Society for Mining, Metallurgy, \& Exploration, Denver, Colorado, USA.

Tracey, S., C. Buxton, C. Gardner, B. Green, K. Hartmann, M. Haward, J. Jabour, J. Lyle, and J. McDonald. 2013. Super trawler scuppered in Australian fisheries management reform. Fisheries 38(8):345-350. http://dx.doi.org/10.1080/03632415.2013.813486

Tsang, S., M. Burnett, P. Hills, and R. Welford. 2009. Trust, public participation and environmental governance in Hong Kong. Environmental Policy and Governance 19(2):99-114. http://dx.doi. org/10.1002/eet.502

UN Human Rights Council. 2008. Protect, respect and remedy: a framework for business and human rights: report of the Special Representative of the Secretary-General on the Issue of Human Rights and Transnational Corporations and Other Business Enterprises. UN Human Rights Council, Geneva, Switzerland.

van Doeveren, V. 2011. Rethinking good governance. Public Integrity 13(4):301-318. https://doi.org/10.2753/PIN1099-9922130401

Van Putten, I. E., C. M. Dichmont, L. X. C. Dutra, O. Thébaud, R. A. Deng, E. Jebreen, R. Owens, R. Pascual, M. Read, and C. Thompson. 2016. Objectives for management of socio-ecological systems in the Great Barrier Reef region, Australia. Regional Environmental Change 16(5):1417-1431. http://dx.doi.org/10.1007/ $\underline{\text { s10113-015-0867-1 }}$

Venticinque, P. F. 2013. Matters of trust: associations and social capital in Roman Egypt. CHS Research Bulletin 1:2.

Wainwright, L. 2015. Stakeholder power dynamics in environmental decision making: a case study of the 2012 FV Margiris 'Super Trawler' fishing dilemma in Australia. Thesis. Uppsala University, Uppsala, Sweden.

Wüstenhagen, R., M. Wolsink, and M. J. Burer. 2007. Social acceptance of renewable energy innovation: an introduction to the concept. Energy Policy 35:2683-2691. http://dx.doi. org/10.1016/i.enpol.2006.12.001 
Appendix 1. Diagram combining the three most widely referenced conceptual models of social licence to operate (SLO) and outlining the relationship between them. The triangle model is indicated in the light grey triangles on the left-hand side of the diagram showing the types of acceptance for SLO by group. The three strand model is shown by the circles which relates SLO to the different types of licences. The pyramid model on the right-hand side of the diagram shows the different stages of SLO and that the highest level of social licence is attained when there is psychological identification. Conceptualized relationships between the models are indicated by the arrows. The black circle in the center depicts the resource use for which SLO applies.

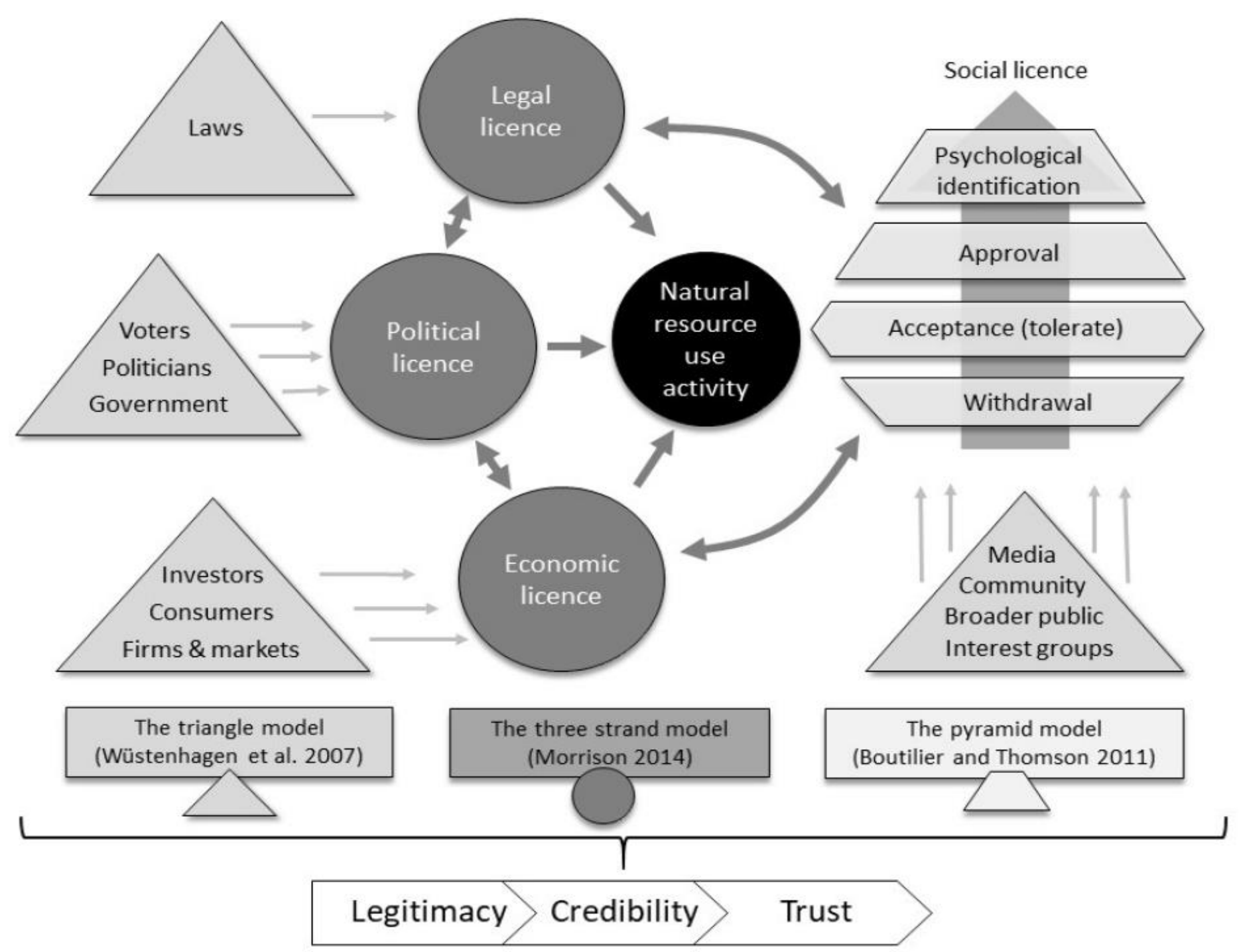

